This content is available online at AESA
e-ISSN: 2456-6632

ORIGINAL RESEARCH ARTICLE

\title{
Effectiveness of integrated weed management in five varieties of aromatic rice in Bangladesh
}

\section{Md. Azhiat-Ul Huq Hia, A.K.M. Mominul Islam*, Shubroto Kumar Sarkar and Md. Parvez Anwar}

Weed Management Laboratory, Department of Agronomy, Bangladesh Agricultural University, Mymensingh-2202, BANGLADESH

*Corresponding author's E-mail: akmmominulislam@bau.edu.bd

\section{ARTICLE HISTORY}

Received: 09 November 2017

Revised received: 16 November 2017

Accepted: 22 November 2017

Keywords

Aromatic rice

Herbicide

Manual weeding

Weed management

\begin{abstract}
An experiment was carried out at the Agronomy Field Laboratory, Bangladesh Agricultural University, Mymensingh, Bangladesh to evaluate the efficacy, rice selectivity and cost-effectiveness of some integrated weed control methods on the productivity of aromatic rice under randomized complete block design with three replications. The experiment consisted of five aromatic rice varieties; Kalijira, BRRI dhan34, BRRI dhan37, BRRI dhan38 and Binadhan-13, and six different weed management practices comprising no weeding, weed free, mechanical + manual weeding, pre-emergence herbicide + manual weeding, post-emergence herbicide + manual weeding, pre -+ post-emergence herbicide. Ten weed species belonging to five families infested the experimental plots. Herbicide treatments provided excellent weed control efficiency and produced much higher net benefit and cost benefit ratio than weedy plot. Among the herbicidal and mechanical treatments, sequential application of Bensulfuran methyl + Acetachlor at early growth stage (pre-emergence herbicide) followed by Pyrazosulfuran ethyl at mid growth stage (post-emergence herbicide) provided the highest weed control efficiency, productivity and net benefit. Single application of Pyrazosulfuran ethyl at mid growth stage followed by one hand weeding performed very close to the pre- + post-emergence herbicide application in terms of productivity and net benefit but in terms of weed control efficiency at 45 days after transplanting application of Bensulfuran methyl + Acetachlor at early growth stage followed by one hand weeding performed very close to pre- + post-emergence herbicide application. Mechanical weeding followed by one hand weeding and application of Bensulfuran methyl + Acetachlor at early growth stage followed by one hand weeding also provided satisfactory results in terms of productivity and economic return. Since manual weeding was less economic, sequential application of pre- and post-emergence herbicides may be recommended for effective weed management in aromatic rice.
\end{abstract}

(C)2017 Agriculture and Environmental Science Academy

Citation of this article: Hia, M.A.U.H., Islam, A.K.M.M., Sarkar, S.K. and Anwar, M.P. (2017). Effectiveness of integrated weed management in five varieties of aromatic rice in Bangladesh. Archives of Agriculture and Environmental Science, 2(3): 308-314, DOI: $10.26832 / 24566632.2017 .020411$

\section{INTRODUCTION}

Thousands of rice land races are considered to exist in Bangladesh (Haque and Miah, 1990). Each of them possesses some special characteristics. Only some of these are unique for quality traits including fineness, aroma, taste and protein contents. Bangladesh has a stock of above 8,000 rice germplasms of which nearly 100 are aromatic (Islam et al., 2016). Cultivation of this rice has been gaining popularity in the country over the recent years, because of its huge demand both for internal consumption and export (Das and Baqui, 2000 ). About $27 \%$ of the total rice cropped area (BBS, 2003), and $12.5 \%$ of the total monsoon rice (BBS, 2005) are occupied by aromatic fine rice varieties of Bangladesh. Moreover, the production of aromatic fine rice is profitable due to its high price over low price coarse milled rice (Raju and Reddy, 2000; Sikdar et al., 2008). Recently, some aromatic fine rice varieties being cultivated in Bangladesh are of international standard and attracting the buyers in the global markets. However, the yield of aromatic rice was lower $\left(1.5-2.0 \mathrm{t} \mathrm{ha}^{-1}\right)$ than the coarse rice (Islam et al., 2010).

Weeding has a great influence on the performance of the associated crop (Kumar and Chopra, 2013, 2016). Thus the best weeding practice needs to be adopted by the farmers with a view to reducing weed infestation and maximizing rice yield. Mechanical and manual methods of weed controls are mainly practiced by the farmers that are very much laborious and time consuming (Kumar and Chopra, 2013, 2016). Moreover, the availability of labor is decreasing due to the out migration of agricultural labors to industries with higher wages than agriculture, increases the need of using herbicides. Use of herbicides may be an alternative method in controlling weeds more easily and effectively at low cost (Rashid et al., 2007). But no single herbicide can control all weeds effectively in all environments. To date very few studies have been conducted to find out the best weed management practices for aromatic rice. On the other hand, a suitable combination of variety and weed management practices might be helpful to increase the yield of aromatic rice. Information on the varietal performance of aromatic rice and its management practices 
are sporadic and scattered (Raju and Reddy, 2000; Rashid et al., 2007; Islam et al., 2010, 2016). In this backdrop, the current research was undertaken to evaluate the efficacy and economics of some integrated weed control methods on the productivity of some selected aromatic rice varieties of Bangladesh grown in monsoon season.

\section{MATERIALS AND METHODS}

Experimental site and crop husbandry: The experiment was carried out at the Agronomy Field Laboratory $\left(24^{\circ} 75^{\prime} \mathrm{N}\right.$ latitude and 90 50' E longitude), Bangladesh Agricultural University, Mymensingh, Bangladesh. The soil is characterized by non-calcareous dark gray floodplain soils having $\mathrm{pH}$ value of 6.5. During the growing season (July-December, 2015), monthly average maximum temperature, minimum temperature, relative humidity, air pressure, wind speed, solar radiation, dew point, pan evaporation and water temperature were $29^{\circ} \mathrm{C}, 20^{\circ} \mathrm{C}, 85 \%, 1006 \mathrm{mb}, 6 \mathrm{~km} \mathrm{~h}^{-1}, 271 \mathrm{~W} \mathrm{~m}^{-2}, 21$ ${ }^{\circ} \mathrm{C}, 3 \mathrm{~mm}$ and $23^{\circ} \mathrm{C}$, respectively, while monthly total rainfall and sunshine hours were 0-387.9 $\mathrm{mm}$ and 84.4-205.9 h, respectively. The average soil temperature at a depth of 5, 10, 20 and $30 \mathrm{~cm}$ were $29,27,27$ and $25^{\circ} \mathrm{C}$, respectively. The experiment was laid out in randomized complete block design with three replications. The experiment was conducted with five aromatic rice varieties viz., Kalijira, BRRI dhan34, BRRI dhan37, BRRI dhan38 and Binadhan-13, and six weed management practices namely; no weeding, weed free, mechanical (by using weeder) + manual (hand pooling) weeding, pre-emergence herbicide + manual weeding, post-emergence herbicide + manual weeding, pre-emergence herbicide + postemergence herbicide during the crop growth period. Here, bensulfuran methyl+acetachlor@750 g ha ${ }^{-1}$ was used as pre -emergence herbicide and pyrazosulfuran ethyl @ 125-150 g $\mathrm{ha}^{-1}$ was used as post-emergence herbicide. After subsequent ploughing followed by laddering, the land was fertilized with $150,97,70,60$ and $12 \mathrm{~kg} \mathrm{ha}^{-1}$ urea, triple super phosphate, muriate of potash, gypsum and zinc sulphate, respectively. All the fertilizers except urea was applied in the unit plots at the time of final land preparation; while urea was top-dressed in three equal splits at 30,50 and 70 days after transplanting (DAT). Thirty five days old seedlings of aromatic rice varieties were transplanted at the rate of two to three seedlings hill $^{-1}$ maintaining row and hill spacing of $25 \mathrm{~cm}$ and $15 \mathrm{~cm}$, respectively. Other intercultural operations were done properly as per standard practices. Pre-emergence herbicide (bensulfuran methyl + acetachlor@750 $\mathrm{g} \mathrm{ha}^{-1}$ ) was applied to the target plots at 5 days after transplantation (DAT) and postemergence herbicide (pyrazosulfuran ethyl @ 125-150 g ha ${ }^{-1}$ ) was applied to the target plots at 30 DAT. The data of weed parameters were collected at 45 DAT, 65 DAT and 85 DAT of rice plants.

The relative density and dry weight, summed dominance ratio of weeds were obtained using the following formula by Janiya and Moody (1989).

Relative density of weed $=\frac{\text { Density of a given weed }}{\text { Total weed density }} \times 100$
Relative dry weight of weed $=\frac{\text { Dry weight of a given weed species }}{\text { Total weed dry weight }} \times 100$

Summed dominance ratio $=\frac{\text { Relative density }+ \text { Relative dry weight }}{2} \times 100$
Weed control efficiency (WCE) was determined by the formula stated in Bangi et al. (2014).

Weed control efficiency $\left(\right.$ WCE) $=\frac{\text { WDC-WDT }}{\text { WDC }} \times 100$

Where,

WDC $=$ weed dry mass from the control plot

WDT $=$ weed dry mass from the treated plot

Weed index (WI) was determined by the following formula stated in Bangi et al. (2014).

Weed index $(\mathrm{WI})=\frac{\mathrm{X}-\mathrm{Y}}{\mathrm{X}} \times 100$

Where,

$\mathrm{X}=$ total yield from the weed free check

$\mathrm{Y}=$ total yield from the treatment for which weed index has to be calculated

Relative yield loss (RYL) and yield increase over control (YOC) were calculated using the following formula:

$$
\begin{aligned}
& \text { RYL }(\%)=\frac{\text { Weed fre yield-Treatment yield }}{\text { Weed free yield }} \times 100 \\
& \text { YOC }(\%)=\frac{\text { Treatment yield-Weedy yield }}{\text { Weedy yield }} \times 100
\end{aligned}
$$

Five hills (excluding border hills) were randomly selected in each plot and uprooted before harvesting for recording the necessary data. The crop was threshed by pedal thresher and grains were sun dried and cleaned. Final grain weight was adjusted to $14 \%$ moisture content using the following formula.

$$
\begin{aligned}
& \text { Moisture }(\%)=\frac{\text { Fresh weight-Oven dry weight }}{\text { Fresh weight }} \times 100 \\
& \text { Adjusted yield at } 14 \% \text { moisture content }(M C)=\frac{100-\% M C}{86(100-14)} \times \text { Fresh weight }
\end{aligned}
$$

The cost of individual head of expenditure was recorded and partial budget analysis was done. The budget consists of the variable cost, gross return, net income and benefit cost ratio.

Statistical analysis of data: The collected data were compiled and tabulated in proper form and were subjected to statistical analysis. Data were analyzed using the analysis of variance (ANOVA) technique with the help of computer package program MSTAT and mean differences were adjudged by Duncan's Multiple Range Test (Gomez and Gomez, 1984).

\section{RESULTS AND DISCUSSION}

Weed composition: The experimental field was infested with the naturally occurring weed community of grass, broad leaved and sedge families. Ten weed species belonging to five families ( 5 grasses, 3 broad leaved and 2 sedges) were found growing on the field (Table 1). Among the weeds, grasses constituted about 53.6\% RD and 72.7\% RDW, followed by broad leaved species (33.3\% RD and 20.2\% RDW) and sedges (12.9\% RD and 7.0\% RDW) (Figures 1 and 2). Based on the summed dominance ratio (SDR) values, grass weed 
species Echinochloa crusgalli (SDR of 42.5) was the most dominant species in the weedy plot followed by the broadleaf weed Monochoria vaginalis (SDR of 25.1). On the other hand, the least dominant weed species of the experimental plot was broadleaf weed Nymphaea nouchali (SDR of 0.83) followed by broadleaf weed species Marsilea crenata (SDR of 0.95) (Table 1).

The results indicate that weedy plot was mostly infested with grasses than broad leaved or sedge weeds. This might be due to the availability of moisture on the field during the experiment because rice weed community is strongly influenced by soil moisture as reported by Juraimi et al. (2009). Bhagat et al. (1999) also recorded the dominance of grasses under higher moisture regimes. According to the SDR values, the grasses were found more aggressive on the study. The variations in the floristic composition and dominance pattern of weeds might be due to the differences in the agro-ecological conditions, cropping pattern, management practices, and weed seed bank composition (Juraimi et al., 2010).

Total weed density: The highest weed density at all DATs was observed in Kalijira whereas the lowest ones in BRRI dhan38 (Table 2). At 45 DAT, the highest weed density (35.6 $\mathrm{m}^{-2}$ ) was found in Kalijira and lowest one $\left(11.9 \mathrm{~m}^{-2}\right)$ was found in BRRI dhan38 which was statistically identical to BRRI dhan34 $\left(13.3 \mathrm{~m}^{-2}\right)$. At 85 DAT, the highest weed density $\left(11.2 \mathrm{~m}^{-2}\right)$ was found in Kalijira which was statistically identical to Binadhan-13 $\left(10.4 \mathrm{~m}^{-2}\right)$ and lowest one $\left(5.5 \mathrm{~m}^{-2}\right)$ was found in BRRI dhan38 (Table 2). It was evident that higher weed density (no. $\mathrm{m}^{-2}$ ) was observed in the local variety Kalijira and lower weed density (no. $\mathrm{m}^{-2}$ ) was observed in the variety BRRI dhan38. Variation of weed population due to variety was also reported by Faruk et al. (2013).

No weed was found in the weed free plot at all DATs as no weeds were allowed to grow as per treatment specification. Among the other treatments, the weedy plot treatment gave the highest weed density at all DATs whereas, the lowest one in pre + post-emergence herbicide treatment (Table 3). At 45 DAT, the highest weed density $\left(45.6 \mathrm{~m}^{-2}\right)$ was found in weedy plot and the lowest weed density $\left(10.7 \mathrm{~m}^{-2}\right)$ was found in pre + post-emergence herbicide treatment which was statistically identical to pre-emergence herbicide + manual weeding $(12.6 \mathrm{~m}$ ${ }^{-2}$ ) (Table 3). At 85 DAT, the highest weed density $\left(14.8 \mathrm{~m}^{-2}\right)$ was found in weedy plot and the lowest weed density $\left(8.4 \mathrm{~m}^{-2}\right)$ was found in pre + post-emergence herbicide treatment which was statistically identical to pre-emergence herbicide + manual weeding treatment $\left(9.3 \mathrm{~m}^{-2}\right)$ (Table 3). Rekha et al. (2002) also reported that weed density was lower in all weeding practices compared to the unweeded control plot.

In the interaction the highest weed densities $82.0 \mathrm{~m}^{-2}, 38.7 \mathrm{~m}^{-2}$ and $38.7 \mathrm{~m}^{-2}$ were found in BRRI dhan $34 \times$ weedy plot at 45,65 and 85 DAT, respectively (Table 4). Mokhlesur (2014) also reported that the highest weed density was found in the interaction between no weeding plot and the cultivar. The lowest weed density $\left(4.20 \mathrm{~m}^{-2}\right)$ at 45 DAT was found in Kalijira $\times$ preemergence herbicide + manual weeding, which was statistically identical with BRRI dhan $38 \times$ pre-emergence herbicide + manual weeding $\left(5.00 \mathrm{~m}^{-2}\right)$, BRRI dhan $38 \times$ pre + post-emergence herbicide $\left(5.33 \mathrm{~m}^{-2}\right)$, BRRI dhan $37 \times$ pre-emergence herbicide + manual weeding $\left(6.00 \mathrm{~m}^{-2}\right)$, BRRI dhan $37 \times$ pre- + postemergence herbicide $\left(6.33 \mathrm{~m}^{-2}\right)$, BRRI dhan $37 \times$ pre- + post emergence herbicide $\left(6.67 \mathrm{~m}^{-2}\right)$, BRRI dhan $38 \times$ postemergence herbicide + manual weeding $\left(7.33 \mathrm{~m}^{-2}\right)$ and Kalijira $\times$ post-emergence herbicide + manual weeding (Table 4$)$.

Weed dry weight: The results exposed that at all DATs, the highest weed dry weights were found in Kalijira whereas the lowest in BRRI dhan38 (Table 2). The highest weed dry weights $22.70 \mathrm{~g} \mathrm{~m}^{-2}, 150.50 \mathrm{~g} \mathrm{~m}^{-2}$ and $58.99 \mathrm{~g} \mathrm{~m}^{-2}$ were found in Kalijira at 45, 65 and 85 DAT, respectively and the lowest values $\left(3.47 \mathrm{~g} \mathrm{~m}^{-2}, 58.95 \mathrm{~g} \mathrm{~m}^{-2}\right.$ and $\left.25.00 \mathrm{~g} \mathrm{~m}^{-2}\right)$ for the same parameter at the same DATs respectively were observed in BRRI dhan38 (Table 2). Similarly, Mokhlesur (2014) also reported that cultivar has significant effect on weed dry weight $\left(\mathrm{g} \mathrm{m}^{-2}\right)$ at different date of DAT.

Among the treatments except weed free plot, the highest weed dry weight was observed in weedy plot whereas the lowest in pre- emergence herbicide + post-emergence herbicide at all sampling dates (Table 3). The highest total weed dry weights $44.5 \mathrm{~g} \mathrm{~m}^{-2}, 194.3 \mathrm{~g} \mathrm{~m}^{-2}$ and $58.48 \mathrm{~g} \mathrm{~m}^{-2}$ at 45,65 and 85 DATs, respectively were observed in weedy plot. At 45 DAT, the lowest total weed dry weight was observed (3.54 $\left.\mathrm{g} \mathrm{m}^{-2}\right)$ in pre + post-emergence herbicide treatment which was statistically identical with pre-emergence herbicide + manual weeding treatment $\left(4.05 \mathrm{~g} \mathrm{~m}^{-2}\right)$ (Table 3$)$. At $85 \mathrm{DAT}$, the lowest total weed dry weight was observed $\left(30.1 \mathrm{~g} \mathrm{~m}^{-2}\right)$ in pre + post-emergence herbicide (Table 3). Similarly Mokhlesur (2014) also reported that cultivar has significant effect on weed dry weight $\left(\mathrm{g} \mathrm{m}^{-2}\right)$ at different DAT and highest weed dry weight $\left(\mathrm{g} \mathrm{m}^{-2}\right)$ was observed in weedy plot or no weeding plot.

At 45 DAT, the highest weed dry weight $\left(113.1 \mathrm{~g} \mathrm{~m}^{-2}\right)$ was found in Kalijira $\times$ weedy plot and the lowest weed dry weight was found $\left(1.2 \mathrm{~g} \mathrm{~m}^{-2}\right)$ in BRRI dhan34 $\times$ pre- + postemergence herbicide, which was statistically identical with BRRI dhan $38 \times$ pre-emergence herbicide + manual weeding $\left(1.5 \mathrm{~g} \mathrm{~m}^{-2}\right)$, BRRI dhan34 $\times$ mechanical weeding + manual weeding $\left(1.5 \mathrm{~g} \mathrm{~m}^{-2}\right)$, BRRI dhan $37 \times$ pre-emergence herbicide + manual weeding $\left(1.8 \mathrm{~g} \mathrm{~m}^{-2}\right)$ and Binadhan-13 $\times$ mechanical + manual weeding $\left(2.0 \mathrm{~g} \mathrm{~m}^{-2}\right)$ (Table 4$)$. At 85 DAT, the highest weed dry weight $\left(117.0 \mathrm{~g} \mathrm{~m}^{-2}\right)$ was found in BRRI dhan $38 \times$ weedy plot and the lowest weed dry weight was found $\left(15.7 \mathrm{~g} \mathrm{~m}^{-2}\right)$ in BRRI dhan $37 \times$ pre-emergence herbicide + manual weeding, which was statistically identical with Kalijira $\times$ weedy plot $\left(16.8 \mathrm{~g} \mathrm{~m}^{-2}\right)$, BRRI dhan $37 \times$ pre- + postemergence herbicide $\left(16.8 \mathrm{~g} \mathrm{~m}^{-2}\right)$ and Kalijira $\times$ pre- + postemergence herbicide $\left(16.9 \mathrm{~g} \mathrm{~m}^{-2}\right)$ (Table 4).

Grain yield: BRRI dhan38 produced the highest grain yield $\left(3.35 \mathrm{t} \mathrm{ha}^{-1}\right)$. The lowest grain yield $\left(1.47 \mathrm{t} \mathrm{ha}^{-1}\right)$ was found in Kalijira (Table 2). The findings are parallel with the findings of Sarkar et al. (2014), Tyeb et al. (2013) and Islam et al. (2012), who reported that variety exerted variable effect on the yield of aromatic rice. Varietal variations regarding grain yield might be due to their variation in genetic constituents. The highest grain yield $\left(3.2 \mathrm{t} \mathrm{ha}^{-1}\right)$ was found in weed free treatment. The lowest grain yield $\left(1.4 \mathrm{tha}^{-1}\right)$ was found in weedy plot treatment (Table 3 ). The treatment of pre + post-emergence herbicide gave the second highest grain yield $\left(2.5 \mathrm{t} \mathrm{ha}^{-1}\right)$. Grain yield was significantly affected by interaction of variety and weed management. The highest grain yield $\left(3.7 \mathrm{t} \mathrm{ha}^{-1}\right)$ was found in BRRI dhan38 in weed free treatment which was statistically identical with (3.6 $\left.\mathrm{t} \mathrm{ha}^{-1}\right)$ Binadhan-13 in weed free treatment. The lowest grain yield $\left(0.68 \mathrm{t} \mathrm{ha}^{-1}\right)$ was produced by BRRI dhan34 in weedy plot treatment which was statistically identical with Binadhan-13 (1.05 $\left.\mathrm{t} \mathrm{ha}^{-1}\right)$ and Kalijira $\left(1.02 \mathrm{t} \mathrm{ha}^{-1}\right)$ in weedy plot (Table 4). 
Weed control efficiency (WCE): The highest weed control efficiency $(100 \%)$ was observed in weed free plot and no weed control efficiency was observed in weedy plot where no weed control measures were taken. Among the other treatments pre + post-emergence herbicide treatment had the highest weed control efficiency in all DAT (Table 5). At 45 DAT, pre + post-emergence herbicide treatment showed the highest WCE $(48.59 \%)$ followed by pre-emergence herbicide + manual weeding $(27.39 \%)$ treatment (Table 5). Anwar et al. (2012) reported that WCE was considered as the percentage of weed dry weight that is reduced by a particular herbicide treatment in comparison with weedy check. Similarly, Alhassan et al. (2015) reported that highest weed control efficiency was observed in weed free plot where manual weeding was performed.

Relative yield loss (RYL) and yield increase over control (YOC): Among the weed management treatments except weedy and weed free plots, pre- + post-emergence herbicide treatment allowed the least yield penalty $(21.87 \%)$, and pre-emergence herbicide + manual weeding treatment showed the highest value of relative yield loss $(35.94 \%)$ whereas, post -emergence herbicide + manual weeding had the highest value of yield increase over control $(69.78 \%)$, and pre + postemergence herbicide had the lowest value of yield increase over control (43.88\%) (Table 5).

Weed index: The highest weed index $(56.56 \%)$ was observed in weedy plot treatment (Figure 3). Among the weed management treatments pre + post-emergence herbicide treatments had the lowest value of weed index (21.87\%) and preemergence herbicide + manual weeding treatments had the highest value of weed index (35.94\%). Bangi et al. (2014) also found the lowest weed index in weed free plot (Figure 3).

Economics of different weed control treatments: Although, from the partial budget analysis, the highest gross return (Tk. 1,55,480) was found in the weed-free treatment, the highest net income (Tk. 75296) and the highest benefit-cost ratio (2.68) were found in the application of pre- + post-emergence herbicide followed by the treatment of post-emergence herbicide + manual weeding (BCR 2.43) (Table 6). The lowest net income (Tk. 29062) and the lowest BCR (1.67) was found in the weedy plot (Table 6). From present study, it was evident that the application of pre-emergence herbicide (Bensulfuran methyl +Acetachlor@750 g ha ${ }^{-1}$ ) + post-emergence herbicide (Pyrazosulfuran ethyl@125-150 g ha $^{-1}$ ) was the most profitable treatment because of the highest net income and the highest BCR. Although the maximum gross return was found in weed-free treatment, due to high cost involvement in manual weeding, the net benefit and BCR were low (1.92) (Table 6).

Table 1. Weed composition found in untreated weedy plots of the experimental field with their summed dominance ratio (SDR).

\begin{tabular}{|c|c|c|c|c|c|c|c|c|}
\hline S.N. & Local name & Scientific name & Family & $\begin{array}{l}\text { Morphological } \\
\text { type }\end{array}$ & Life cycle & $\begin{array}{l}\text { RD } \\
(\%)\end{array}$ & $\begin{array}{l}\text { RDW } \\
(\%)\end{array}$ & $\begin{array}{l}\text { SDR } \\
(\%)\end{array}$ \\
\hline 1 & Shama & $\begin{array}{l}\text { Echinochloa crusgalli (L.) } \\
\text { Beauv. }\end{array}$ & Gramineae & Grass & Annual & 24.19 & 60.81 & 42.50 \\
\hline 2 & Pani kachu & $\begin{array}{l}\text { Monochoria vaginalis } \\
\text { (Burm. F.) C. Presl. }\end{array}$ & Pontederiaceae & Broad leaved & Perennial & 30.24 & 19.87 & 25.06 \\
\hline 3 & Sabuj nakful & Cyperus difformis & Gramineae & Grass & Annual & 12.90 & 2.33 & 7.61 \\
\hline 4 & Anguli ghash & Digitaria sanguinalis L. & Gramineae & Grass & Annual & 12.50 & 0.63 & 6.56 \\
\hline 5 & Pani chaise & $\begin{array}{l}\text { Eleocharis atropurpurea } \\
\text { (Retz.) J. \& K. Presl }\end{array}$ & Cyperaceae & Sedge & Annual & 10.48 & 0.42 & 5.45 \\
\hline 6 & Arail & Leersia hexandra & Gramineae & Grass & Perennial & 1.61 & 8.28 & 4.94 \\
\hline 7 & Bara Chucha & Cyperus iria & Cyperaceae & Sedge & Annual & 2.42 & 6.62 & 4.52 \\
\hline 8 & Angta & Paspalum scrobiculatum L. & Gramineae & Grass & Perennial & 2.42 & 0.69 & 1.55 \\
\hline 9 & Sushni shak & Marsilea crenata & Marsileaceae & Broad leaved & Annual & 1.61 & 0.29 & 0.95 \\
\hline 10 & Shapla & Nymphaea nouchali & Nymphaeaceae & Broad leaved & Annual & 1.61 & 0.05 & 0.83 \\
\hline
\end{tabular}

RD- Relative density, RDW- Relative dry weight.

Table 2. Weed density, weed dry weight and grain yield in aromatic rice as influenced by variety.

\begin{tabular}{|c|c|c|c|c|c|c|c|}
\hline \multirow{2}{*}{ Variety } & \multicolumn{3}{|c|}{ Weed density $\left(\right.$ no. $\mathbf{~ m}^{-2}$ ) } & \multicolumn{3}{|c|}{ Weed dry weight $\left(\mathrm{g} \mathrm{m}^{-2}\right)$} & \multirow{2}{*}{$\begin{array}{l}\text { Grain yield } \\
\qquad\left(t \text { ha }^{-1}\right)\end{array}$} \\
\hline & 45 DAT & 65 DAT & 85 DAT & 45 DAT & 65 DAT & 85 DAT & \\
\hline Kalijira & $35.56 \mathrm{a}$ & $26.89 \mathrm{a}$ & $11.22 \mathrm{a}$ & $22.70 \mathrm{a}$ & $150.50 \mathrm{a}$ & $58.99 \mathrm{a}$ & $1.47 \mathrm{~d}$ \\
\hline BRRI dhan34 & $13.28 \mathrm{~d}$ & $19.89 \mathrm{~b}$ & $9.00 \mathrm{~b}$ & $5.88 \mathrm{c}$ & $104.41 \mathrm{c}$ & $38.87 \mathrm{c}$ & $2.17 \mathrm{c}$ \\
\hline BRRI dhan37 & $15.83 \mathrm{c}$ & $14.67 \mathrm{c}$ & $9.39 b$ & $6.30 \mathrm{c}$ & $119.29 b$ & $46.56 \mathrm{~b}$ & $2.33 b$ \\
\hline BRRI dhan38 & $11.97 \mathrm{~d}$ & $13.56 \mathrm{c}$ & $5.50 \mathrm{c}$ & $3.47 \mathrm{~d}$ & $58.95 \mathrm{~d}$ & $25.00 \mathrm{e}$ & $3.35 \mathrm{a}$ \\
\hline Binadhan-13 & $20.11 b$ & $13.83 \mathrm{c}$ & $10.44 \mathrm{ab}$ & $12.99 \mathrm{~b}$ & $108.42 \mathrm{c}$ & $33.80 \mathrm{~d}$ & $2.93 b$ \\
\hline CV (\%) & 17.6 & 15.41 & 15.23 & 7.31 & 11.48 & 13.58 & 27.66 \\
\hline Level of significance & $* *$ & $* *$ & $* *$ & $* *$ & $* *$ & $* *$ & $* *$ \\
\hline
\end{tabular}

In a column, values having similar letter do not differ significantly whereas values with dissimilar letter differ significantly as per DMRT. **Significant at $1 \%$ level of probability. 
Table 3. Weed density, weed dry weight and grain yield in aromatic rice as influenced by weed management.

\begin{tabular}{|c|c|c|c|c|c|c|c|}
\hline \multirow{2}{*}{ Weed Management } & \multicolumn{3}{|c|}{ Weed density (no. m $^{-2}$ ) } & \multicolumn{3}{|c|}{ Weed dry weight $\left(\mathrm{g} \mathrm{m}^{-2}\right)$} & \multirow{2}{*}{ Grain yield $\left(\mathrm{t} \mathrm{ha}^{-1}\right)$} \\
\hline & 45 DAT & 65 DAT & 85 DAT & 45 DAT & 65 DAT & 85 DAT & \\
\hline Weedy plot & $45.60 \mathrm{a}$ & $23.60 \mathrm{a}$ & $14.80 \mathrm{a}$ & $44.48 \mathrm{a}$ & $194.32 \mathrm{a}$ & $58.48 \mathrm{a}$ & $1.39 \mathrm{~d}$ \\
\hline Weed free plot & & Weed free & & & Weed free & & $3.20 \mathrm{a}$ \\
\hline $\begin{array}{l}\text { Mechanical weeding }+ \text { manual } \\
\text { weeding }\end{array}$ & $21.47 \mathrm{c}$ & $20.93 b$ & $10.67 \mathrm{c}$ & $4.75 b$ & $121.38 \mathrm{~b}$ & $57.90 \mathrm{a}$ & $2.18 \mathrm{c}$ \\
\hline $\begin{array}{l}\text { Pre-emergence herbicide }+ \text { manual } \\
\text { weeding }\end{array}$ & $12.64 d$ & $20.80 \mathrm{~b}$ & $9.33 d$ & $4.05 \mathrm{c}$ & $130.10 \mathrm{~b}$ & $42.46 \mathrm{~b}$ & $2.05 \mathrm{c}$ \\
\hline $\begin{array}{l}\text { Post-emergence herbicide }+ \text { manual } \\
\text { weeding }\end{array}$ & $25.66 \mathrm{~b}$ & $21.87 \mathrm{ab}$ & $11.47 \mathrm{~b}$ & $4.79 b$ & $108.29 \mathrm{c}$ & $54.97 \mathrm{a}$ & $2.36 \mathrm{c}$ \\
\hline $\begin{array}{l}\text { Pre-emergence }+ \text { post-emergence } \\
\text { herbicide }\end{array}$ & $10.73 d$ & $19.40 \mathrm{~b}$ & $8.40 \mathrm{~d}$ & $3.54 \mathrm{c}$ & $95.79 \mathrm{~d}$ & $30.06 \mathrm{c}$ & $2.50 \mathrm{~b}$ \\
\hline CV $(\%)$ & 17.6 & 15.41 & 15.23 & 7.31 & 11.48 & 13.58 & 7.06 \\
\hline Level of significance & $* *$ & $* *$ & $* *$ & $* *$ & $* *$ & $* *$ & $* *$ \\
\hline
\end{tabular}

In a column, values having similar letter do not differ significantly whereas values with dissimilar letter differ significantly as per DMRT. ${ }^{* *}$ Significant at $1 \%$ level of probability.

Table 4. Interaction effect of variety and weed management practices on weed density, weed dry weight and yield in aromatic rice.

\begin{tabular}{|c|c|c|c|c|c|c|c|c|}
\hline & Interaction & \multicolumn{3}{|c|}{ Weed density $\left(\right.$ no.m $\left.^{-2}\right)$} & \multicolumn{3}{|c|}{ Weed dry weight $\left(\mathrm{g} \mathrm{m}^{-2}\right)$} & \multirow{2}{*}{$\begin{array}{c}\text { Grain } \\
\text { yield } \\
\left(\mathrm{t} \mathrm{ha}^{-1}\right)\end{array}$} \\
\hline Variety & Weed management & 45 DAT & 65 DAT & 85 DAT & 45 DAT & 65 DAT & 85 DAT & \\
\hline \multirow{6}{*}{ Kalijira } & Weedy plot & $43.33 b$ & $35.33 \mathrm{a}$ & $18.00 \mathrm{ab}$ & $113.12 \mathrm{a}$ & $126.47 \mathrm{e}$ & $16.79 \mathrm{j}$ & $1.02 \mathrm{klm}$ \\
\hline & Weed free plot & \multicolumn{6}{|c|}{ Weed free } & $2.37 \mathrm{f}-\mathrm{j}$ \\
\hline & Mechanical weeding + manual weeding & $9.33 \mathrm{gh}$ & $29.33 \mathrm{bc}$ & $10.67 \mathrm{~d}-\mathrm{g}$ & $9.95 \mathrm{e}$ & $201.95 \mathrm{c}$ & $45.13 \mathrm{fg}$ & $1.11 \mathrm{jkl}$ \\
\hline & Pre-emergence herbicide + manual weeding & $4.20 \mathrm{~h}$ & $24.67 \mathrm{~cd}$ & 6.67ghi & $4.31 \mathrm{hij}$ & $164.12 \mathrm{~d}$ & $22.64 \mathrm{i}$ & $1.27 \mathrm{i}-1$ \\
\hline & Post-emergence herbicide + manual weeding & $8.30 \mathrm{~h}$ & $34.67 \mathrm{ab}$ & $9.33 \mathrm{e}-\mathrm{h}$ & $5.11 \mathrm{ghi}$ & $299.56 \mathrm{a}$ & $48.52 \mathrm{ef}$ & $1.26 \mathrm{i}-1$ \\
\hline & Pre-emergence + post-emergence herbicide & $6.67 \mathrm{~h}$ & $37.33 \mathrm{a}$ & $9.33 \mathrm{e}-\mathrm{h}$ & $3.72 \mathrm{ijk}$ & $110.92 \mathrm{e}$ & $16.93 \mathrm{j}$ & $1.80 \mathrm{~h}-\mathrm{k}$ \\
\hline \multirow{6}{*}{$\begin{array}{c}\text { BRRI } \\
\text { dhan34 }\end{array}$} & Weedy plot & $82.00 \mathrm{a}$ & $38.67 \mathrm{a}$ & $21.33 \mathrm{a}$ & $18.71 \mathrm{~d}$ & $303.28 \mathrm{a}$ & $25.36 \mathrm{i}$ & $0.68 \mathrm{~m}$ \\
\hline & Weed free plot & \multicolumn{6}{|c|}{ Weed free } & $3.17 \mathrm{c}-\mathrm{g}$ \\
\hline & Mechanical weeding + manual weeding & $44.67 b$ & 13.33ghi & $10.67 \mathrm{~d}-\mathrm{g}$ & $1.46 \mathrm{n}$ & $76.83 \mathrm{gh}$ & $61.96 \mathrm{~d}$ & $2.14 \mathrm{hij}$ \\
\hline & Pre-emergence herbicide + manual weeding & $24.67 \mathrm{ef}$ & $18.67 \mathrm{~d}-\mathrm{g}$ & $18.67 \mathrm{ab}$ & $7.40 \mathrm{f}$ & $115.19 \mathrm{e}$ & $86.43 b$ & $2.27 \mathrm{~g}-\mathrm{j}$ \\
\hline & Post-emergence herbicide + manual weeding & $47.33 b$ & $23.33 \mathrm{cde}$ & $12.00 \mathrm{c}-\mathrm{f}$ & $6.47 \mathrm{fg}$ & $68.36 \mathrm{ghi}$ & 30.48hi & $2.71 \mathrm{e}-\mathrm{i}$ \\
\hline & Pre-emergence + post-emergence herbicide & $14.67 \mathrm{~g}$ & $25.33 \mathrm{~cd}$ & $4.67 \mathrm{i}$ & $1.21 \mathrm{n}$ & 62.79 hij & $28.99 \mathrm{hi}$ & 2.91d-h \\
\hline \multirow{6}{*}{$\begin{array}{l}\text { BRRI } \\
\text { dhan37 }\end{array}$} & Weedy plot & $24.67 \mathrm{ef}$ & $19.33 \mathrm{~d}-\mathrm{f}$ & 7.33ghi & $4.21 \mathrm{~h}-\mathrm{k}$ & $300.01 \mathrm{a}$ & $77.53 b c$ & 2.031 \\
\hline & Weed free plot & \multicolumn{6}{|c|}{ Weed free } & $2.67 \mathrm{~cd}$ \\
\hline & Mechanical weeding + manual weeding & $6.67 \mathrm{~h}$ & $14.00 \mathrm{f}-\mathrm{i}$ & $8.00 \mathrm{f}-\mathrm{i}$ & 5.06hi & $55.91 \mathrm{hij}$ & $83.75 \mathrm{bc}$ & $2.23 \mathrm{~d}-\mathrm{h}$ \\
\hline & Pre-emergence herbicide + manual weeding & $6.00 \mathrm{~h}$ & $9.33 \mathrm{hi}$ & $6.00 \mathrm{hi}$ & $1.84 \mathrm{mn}$ & $203.79 c$ & $15.73 \mathrm{j}$ & $2.29 \mathrm{~d}-\mathrm{h}$ \\
\hline & Post-emergence herbicide + manual weeding & $36.00 \mathrm{c}$ & $23.33 \mathrm{cde}$ & $8.00 \mathrm{f}-\mathrm{i}$ & $4.15 \mathrm{~h}-\mathrm{k}$ & $51.52 \mathrm{ij}$ & $85.55 b$ & $2.44 \mathrm{e}-\mathrm{h}$ \\
\hline & Pre-emergence + post-emergence herbicide & $6.33 \mathrm{~h}$ & 15.33 fgh & $3.67 \mathrm{i}$ & $5.56 \mathrm{gh}$ & $104.49 \mathrm{ef}$ & $16.81 \mathrm{j}$ & $2.33 \mathrm{efg}$ \\
\hline \multirow{7}{*}{$\begin{array}{c}\text { BRRI } \\
\text { dhan38 }\end{array}$} & Weedy plot & $45.33 b$ & $22.67 \mathrm{de}$ & $15.33 \mathrm{bc}$ & $21.81 \mathrm{c}$ & $115.45 \mathrm{e}$ & $117.03 \mathrm{a}$ & $2.21 \mathrm{~g}-\mathrm{j}$ \\
\hline & Weed free plot & \multicolumn{6}{|c|}{ Weed free } & $3.72 \mathrm{a}$ \\
\hline & Mechanical weeding + manual weeding & $32.00 \mathrm{~cd}$ & $20.67 \mathrm{def}$ & $13.33 \mathrm{cde}$ & $5.27 \mathrm{gh}$ & $227.03 b$ & $74.73 \mathrm{c}$ & $3.02 \mathrm{c}-\mathrm{f}$ \\
\hline & Pre-emergence herbicide + manual weeding & $5.00 \mathrm{hi}$ & $17.33 \mathrm{efg}$ & $6.00 \mathrm{hi}$ & $1.45 n$ & $125.76 \mathrm{e}$ & $49.60 \mathrm{ef}$ & $3.26 \mathrm{c}-\mathrm{h}$ \\
\hline & Post-emergence herbicide + manual weeding & $7.33 \mathrm{~h}$ & $19.33 \mathrm{~d}-\mathrm{g}$ & $15.33 \mathrm{bc}$ & $4.99 \mathrm{hi}$ & $67.57 \mathrm{ghi}$ & $61.19 \mathrm{~d}$ & $3.22 \mathrm{c}-\mathrm{h}$ \\
\hline & Pre-emergence + post-emergence herbicide & $5.33 \mathrm{hi}$ & $8.00 \mathrm{i}$ & 6.33ghi & $4.31 \mathrm{hij}$ & $114.71 \mathrm{e}$ & $51.40 \mathrm{ef}$ & $3.44 \mathrm{bc}$ \\
\hline & Weedy plot & $32.67 \mathrm{~cd}$ & $8.00 \mathrm{i}$ & $14.67 \mathrm{bcd}$ & $64.55 b$ & $126.37 \mathrm{e}$ & $55.71 \mathrm{de}$ & $1.05 \mathrm{klm}$ \\
\hline \multirow{7}{*}{$\begin{array}{c}\text { Binadhan- } \\
13\end{array}$} & Weed free plot & \multicolumn{6}{|c|}{ Weed free } & $3.58 \mathrm{ab}$ \\
\hline & Mechanical weeding + manual weeding & $14.67 \mathrm{~g}$ & $19.67 \mathrm{~d}-\mathrm{g}$ & $10.67 \mathrm{~d}-\mathrm{g}$ & $2.001 \mathrm{mn}$ & $45.19 \mathrm{ij}$ & $23.93 \mathrm{i}$ & $2.38 \mathrm{f}-\mathrm{i}$ \\
\hline & Pre-emergence herbicide + manual weeding & $23.33 \mathrm{ef}$ & $19.33 \mathrm{~d}-\mathrm{g}$ & 6.67ghi & $5.27 \mathrm{gh}$ & $41.64 \mathrm{j}$ & $37.88 \mathrm{gh}$ & $1.87 \mathrm{~h}-\mathrm{k}$ \\
\hline & Post-emergence herbicide + manual weeding & $29.33 \mathrm{de}$ & $17.33 \mathrm{efg}$ & $12.67 \mathrm{cde}$ & $3.24 \mathrm{jkl}$ & $54.45 \mathrm{hij}$ & $49.13 \mathrm{ef}$ & $2.21 \mathrm{c}-\mathrm{f}$ \\
\hline & Pre-emergence + post-emergence herbicide & $20.67 f$ & $18.67 \mathrm{~d}-\mathrm{g}$ & $18.00 \mathrm{ab}$ & $2.89 \mathrm{klm}$ & $86.04 \mathrm{fg}$ & $36.16 \mathrm{gh}$ & $2.54 \mathrm{cde}$ \\
\hline & $\mathrm{CV}(\%)$ & 17.6 & 15.41 & 15.23 & 7.31 & 11.48 & 13.58 & 5.46 \\
\hline & Level of significance & $* *$ & $* *$ & $* *$ & $* *$ & $* *$ & $* *$ & $*$ \\
\hline
\end{tabular}

*Significant at $5 \%$ level of probability, In a column, values having similar letter do not differ significantly whereas values with dissimilar letter differ significantly as per DMRT; ** Significant at $1 \%$ level of probability. 
Table 5. Weed control efficiency, weed inflicted relative yield loss and yield increase over control of rice due to different weed management treatments.

\begin{tabular}{|c|c|c|c|c|c|}
\hline \multirow{2}{*}{ Weed management } & \multicolumn{3}{|c|}{ Weed control efficiency (\%) } & \multirow{2}{*}{ RYL (\%) } & \multirow{2}{*}{ YOC (\%) } \\
\hline & 45 DAT & 65 DAT & 85 DAT & & \\
\hline Weedy plot & 0 & 0 & 0 & 56.56 & 0 \\
\hline Weed free plot & 100 & 100 & 100 & 0 & 130.212 \\
\hline Mechanical weeding + manual weeding & 89.32 & 37.53 & 0.99 & 31.88 & 56.83 \\
\hline Pre-emergence herbicide + manual weeding & 90.89 & 33.04 & 27.39 & 35.94 & 47.48 \\
\hline Post-emergence herbicide + manual weeding & 89.23 & 44.27 & 6.00 & 26.25 & 69.78 \\
\hline Pre-emergence + post-emergence herbicide & 92.04 & 50.70 & 48.59 & 21.87 & 43.88 \\
\hline
\end{tabular}

Table 6. Cost effectiveness (partial cost analysis) of different weed control treatments.

\begin{tabular}{lcccccc}
\hline & $\begin{array}{c}\text { Variable } \\
\text { cost except } \\
\text { herbicide } \\
\text { and weeding } \\
\text { cost }\end{array}$ & $\begin{array}{c}\text { Herbicide } \\
\text { cost }\end{array}$ & $\begin{array}{c}\text { Laborer cost } \\
\text { for spraying/ } \\
\text { weeding }\end{array}$ & Total cost & $\begin{array}{c}\text { Gross } \\
\text { income }\end{array}$ & $\begin{array}{c}\text { Net income } \\
\text { Benefit-cost } \\
\text { ratio }\end{array}$ \\
\hline $\begin{array}{l}\text { Weedy plot } \\
\text { Weed free plot }\end{array}$ & $\begin{array}{c}43458 \\
42038\end{array}$ & 0 & 0 & 43458 & 72520 & 29062 \\
$\begin{array}{l}\text { Mechanical weeding } \\
\text { manual weeding }\end{array}$ & 44708 & 0 & 59000 & 81038 & 155480 & 74442 \\
$\begin{array}{l}\text { Pre-emergence herbicide }+ \\
\text { manual weeding }\end{array}$ & 43458 & 617.5 & 5720 & 49795.5 & 106280 & 56484.5 \\
$\begin{array}{l}\text { Post-emergence herbicide }+ \\
\text { manual weeding }\end{array}$ & 43458 & 308.75 & 5720 & 49486.75 & 120200 & 70713.25 \\
$\begin{array}{l}\text { Pre- }+ \text { post-emergence } \\
\text { herbicide }\end{array}$ & 42938 & 926.25 & 1040 & 44904.25 & 120200 & 75295.75 \\
\hline
\end{tabular}

In a column, values having similar letter do not differ significantly whereas values with dissimilar letter differ significantly as per DMRT. $* *$ Significant at $1 \%$ level of probability.

\section{mGrass $\square$ Sedge $\quad$ Broad leaved}

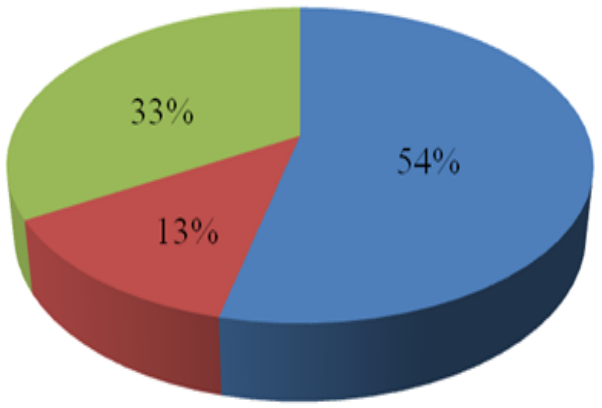

Figure 1. Relative density of different weeds.

\section{- Grass $\square$ Sedge $\quad$ Broad leaved}

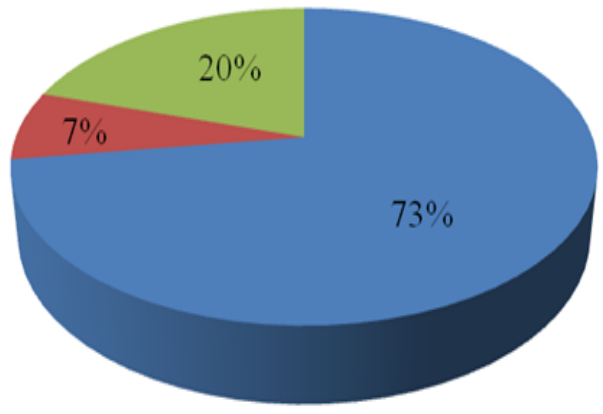

Figure 2. Relative dry weight of different weed groups.

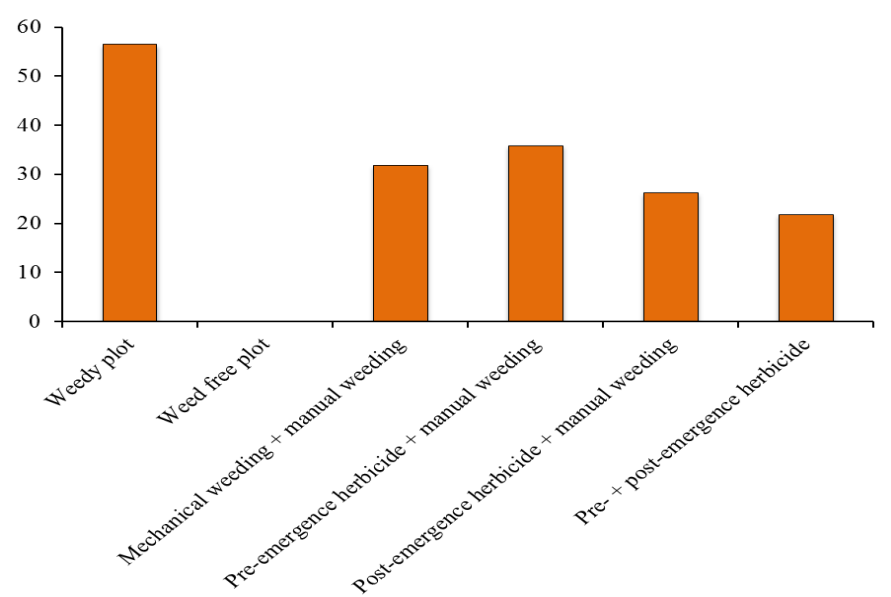

Figure 3. Weed Index of different weed management practices.

\section{Conclusions}

The yield of aromatic rice is lower than that of coarse and medium rice varieties but its higher market price makes it more remunerative to the farmers. Among the several factors, weed management in aromatic rice play an important role for lowering its grain yield. The farmers of Bangladesh mainly practiced manual and mechanical weeding to manage the weeds from the crop fields. Recently they started to adopt chemical weed management. Moreover, before making the final choice of any weed control method, farmers' available resources e.g., labour, have to be considered first. The current research revealed that despite high weed control efficiency, manual weeding is not cost-effective, whilst chemical weed controls are highly efficient and economic as well. Among the tested herbicides, Bensulfuran methyl +Acetachlor@750 g ha $^{-1}$ followed by Pyrazosulfuran ethyl@125-150 $\mathrm{g} \mathrm{ha}^{-1}$ may be considered for their high efficacy and cost-effectiveness for weed management in aromatic rice. 
Conflict of interest: The authors declare that there is no conflict of interests regarding the publication of this paper.

Open Access: This is open access article distributed under the terms of the Creative Commons Attribution License, which permits unrestricted use, distribution, and reproduction in any medium, provided the original author(s) and the source are credited.

\section{REFERENCES}

Alhassan, J., Dadari, S.A., Babaji, B.A. and Shebayan, J.A.Y. (2015). Weed control efficiency of management practices of lowland paddy production in Sudan Savanna Ecology. Journal of Biology, Agriculture and Healthcare, 5: 105-113.

Anwar, M.P., Juraimi, A.S., Puteh, A., Man, A. and Rahman, M.M. (2012). Efficacy, phytotoxicity and economics of different herbicides in aerobic rice. Acta Agriciculture Scandinevia, Section B - Soil and Plant Science, 62 (7): 604-615. doi:10.1080/09064710.2012.681060.

Bangi, S.S., Lal, E.P., Bangi, S.S. and S.U.T. (2014). Effect of herbicides on weed control efficiency (WCE) and yield attributes in brinjal (Solanum melongena L.) IOSR Journal of Agriculture and Veterinary Science, 7(6): 59-65.

BBS, (2005). Statistical Yearbook of Bangladesh. Stat. Div. Min. Plan. pp. 67-68.

BBS, (2003). Statistical Year book of Bangladesh. Dhaka, Bangladesh.

Bhagat, R.M., Bhuiyan, S.I., Moody, K. and Estorninos, L.E. (1999). Effect of water, tillage and herbicide on ecology of weed communities in intensive wet-seeded rice system. Crop Protection, 18, 293-303. doi:10.1016/S0261-2194(99)00024-1.

Das, T. and Baqui, M.A. (2000). Aromatic rices of Bangladesh, in: Singh R. K., S.U.S. and K.G.S. (Ed.), Aromatic Rices. Oxford and IBH Publishing Co. Pvt. Ltd., New Delhi and Calcutta, India, pp. 184-187.

Faruk, M.S.A., Salam, M.A., Jannat, M. and Rabbani, M.G. (2013). Effect of herbicide Prechlor on the performance of T. aman rice. Journal of the Bangladesh Agricultural University, 11(2): 257-264.

Gomez, K.A. and Gomez, A.A. (1984). Statistical Procedures for Agricultural Research, 2nd editio. ed. Int. Rice Res. Inst., John Wiley and Sons, New York.

Haque, M.E. and Miah, N.M., 1990. Rice genetic resources in Bangladesh its past, present and future, in: Rahman L, Shaikh, M.A.Q. (Ed.), Plant Breeding in Bangladesh, Proceedings of the First National Symposium 1989. Bangladesh Jute Res. Inst. and Plant Breeding and Genetics Society of Bangladesh, Dhaka, Bangladesh, pp. 219-224.

Islam, M., Hossain, M., Chowdhury, M. and Hannan, M. (2010). Effect of nitrogen and transplanting date on yield and yield components of aromatic rice. Journal of the Bangladesh Agricultural University, 6: 291-296. doi:10.3329/ jbau.v6i2.4824

Islam, M.S., Sarkar, M.A.R., Uddin, S. and Parvin, S. (2012). Yield of fine rice varieties as influenced by integrated management of poultry manure urea super granules and prilled urea. Journal of Environmental Science and Natural Resources, 5: 129-132.

Islam, M.Z., Khalequzzaman, M., Bashar, M.K., Ivy, N.A., Haque, M.M. and Mian, M.A.K. (2016). Variability assessment of aromatic and fine rice germplasm in bangladesh based on quantitative traits. The Scientific World Journal, doi:10.1155/2016/2796720.

Janiya, J.D. and Moody, K. (1989). Weed populations in transplanted and wet seeded rice as affected by weed control method. Tropical Pest Management, 35: 8-11. doi:10.1080/09670878909371311.

Juraimi, Abdul Shukor, Begum, Mahfuza, Mohd. Yusof, Mohamad Najib, and Man, A. (2010). Efficacy of herbicides on the control weeds and productivity of direct seeded rice under minimal water conditions. Plant Protection Quarterly, 25(1): 19-25.

Juraimi, A.S., Mohamad Najib, M.Y., Begum, M., Anuar, A.R., Azmi, M. and Puteh, A. (2009). Critical period of weed competition in direct seeded rice under saturated and flooded conditions. Pertanika Journal of Tropical Agricultural Science, 32: 305-316.

Kumar, V. and Chopra, A.K. (2013). Reduction of weeds and improvement of soil quality and yield of wheat by tillage in Northern Great Plains of Ganga River in India. International Journal of Agricultural Science Research, 2(8): 249-257.

Kumar, V. and A.K. Chopra (2016). Influence of summer tillage on soil characteristics, weeds diversity and crop yield of certain vegetable crops grown in Tarai region of Ganga River, India. International Journal of Agricultural Science Research, 5(3): 040-050.

Mokhlesur, M.R. (2014). Effect of weeding regime on the performance of transplant aman rice. Bangladesh Agricultural University.

Raju, R.A. and Reddy, M.N. (2000). Effect of urea amended neem triferpens jelly. $\mathrm{N}$ rates and time of application on winter rice (Oriza sativa). Indian Journal of Agronomy, 42(2): 278-281.

Rashid, M.H., Uddin, M.H., Islam, A.K.M.M., Alam, A.H.M.J. and Anwar, M.P. (2007). Efficiencies and economics of some weed control methods in transplant aman rice cv. BRRI dhan32. Bangladesh Journal of Crop Science, 18, 259-264. doi:citeulikearticle-id:7654426.

Rekha, K. Bhanu, Raju, M. S., Reddy, M.D. (2002). Effect of Herbicides in Transplanted Rice. Indian Journal of Weed Science, 34 (1\&2): 123-125.

Sarkar, S.K., Sarkar, M.A.R., Islam, N. and Paul, S.K. (2014). Yield and quality of aromatic fine rice as affected by variety and nutrient management. Journal of the Bangladesh Agricultural University, 12: 279. doi:10.3329/jbau.v12i2.28683.

Sikdar, M.S.I., Rahman, M.M., Islam, M.S., Yeasmin, M.S. and Akhter, M.M. (2008). Effect of nitrogen level on aromatic rice varieties and soil fertility status. International Journal of Sustainable Crop Production, 3: 49-54.

Tyeb, A., Paul, S.K. and Samad, M.A. (2013). Performance of variety and spacing on the yield and yield contributing characters of transplanted aman rice. Journal of Agroforestry and Environment, 40: 595-597. 